\title{
Aantekeninge/Notes
}

\section{Remarks on lending reforms ushered in by regulation 23A of the Affordability Assessment Regulations}

\section{Introduction}

The prescriptive reforms espoused by Regulation 23A of the National Credit Amendment Act 19 of 2014 (hereafter 'Regulation 23A') arguably should be commended as a proactive step in the quest for equity in the lender-borrower relationship in South Africa. It comes on the heels of the amendment of 82 of the National Credit Act 34 of 2005 (hereafter 'the NCA') which historically gave the credit provider the power to design an evaluative mechanism to determine affordability. While lending and borrowing are not recent phenomena (Finlay Consumer Credit Fundamentals (2009) 33; Morgan 'History and economics of suretyship' 1927 Cornell L. Rev. 153) it is the economic consequences of that relationship that have caught the attention of both financial participants and the regulators. More specifically a familiar feature among regulators has been an intensified effort aimed at reforming procedures that address consumer over-indebtedness (Niemi-Kiesiläinen 'Consumer bankruptcy in comparison: Do we cure a market failure or a social problem? 1999 Osgoode Hall L.J. 473; Tabb 'Lessons from the globalization of consumer bankruptcy' (2005) 30 Law \& Soc. Inquiry 763). Such strategies are premised on an understanding that overindebtedness is a social malaise and that there is need to protect consumers from the economic distress that comes with indebtedness (Turunen and Hiilamo 'Health effects of indebtedness: a systematic review' 2014 BMC Public Health 489; Averett and Smith 'Financial hardship and obesity' 2014 Economics and Human Biology 201). Equally critical is the realisation that indebtedness has an impact on the level of economic activity and as consequence, on the stability of the financial system (Niemi-Kiesiläinen 'Consumer bankruptcy in comparison: Do we cure a market failure or a social problem?’ 1999 Osgood Hall L.J. 473; Tabb 'Lessons from the globalization of consumer bankruptcy' $2005 \mathrm{LaW}$ \& Soc. Inquiry 763).

Regulators in South Africa have grappled with the issue around lending since the now-repealed Usury Act 73 of 1968 as well as the Credit Agreements Act 75 of 1980 , the forerunners to the regulation of consumer credit. Since then the National Credit Act 34 of 2005 has sought to provide comprehensive mechanisms for minimising both reckless lending and irresponsible borrowing. More specifically, its preamble states that the purpose of the NCA is to promote a fair and non-

How to cite: Kawadza 'Remarks on lending reforms ushered in by regulation 23A of the Affordability Assessment Regulations' 2017 De Jure 163-172

http://dx.doi.org/10.17159/2225-7160/2018/v51n1a10 
discriminatory marketplace for access to consumer credit and for that purpose to provide for the general regulation of consumer credit and improved standards of consumer information; to promote black economic empowerment and ownership within the consumer credit industry; to prohibit certain unfair credit and credit-marketing practices; to promote responsible credit granting and use and for that purpose to prohibit reckless credit granting; to provide for debt re-organisation in cases of over-indebtedness.

Despite that objective, consumer indebtedness statistics point to the fact that the NCA has not been highly effective (Ellyne and Jourdan 'Did the National Credit Act of 2005 facilitate a credit boom and bust In South Africa?' available at www.essa.org.za/fullpaper/essa_2798.pdf, accessed on 2018-04-01). The new guidelines ushered by Regulation 23A have therefore been hailed as a game changer (The Department of Trade and Industry Media statement 'The DTI Publishes Affordability Assessment Regulations for public comment', available at https://www.thedti.gov.za/ editmedia.jsp?id $=3104$, accessed on 2018-04-01). This is mainly because the new framework introduces a more stringent lending criterion aimed at promoting responsible lending and borrowing in the regulated credit market. It is the purpose of this note to examine the new dispensation, to describe the paradigm shift and to consider if and how it archives the much-needed objective of arresting household or consumer indebtedness by avoiding reckless lending as well as encouraging responsible borrowing in South Africa.

\section{Consumer credit and indebtedness in perspective}

It has been recognised that household credit health is linked to economic welfare (Prinsloo 'Household debt, wealth and saving'2002 SA Reserve Bank Quarterly Bulletin 63; Baiyegunhi, Fraser and Darroch 'Credit constraints and household welfare in the Eastern Cape Province, South Africa' 2010 African Journal of Agricultural Research 2243). More specifically,

[e]asing the access to credit is considered by classic economic theory an important factor for economic growth and for contributing to economic wellbeing. Debt may be necessary to maintain a stable consumption level and to boost the economy in more timid periods (Porto 'Over-indebtedness in Brazil: Do we need more regulation?', available at http://ssrn.com/abstract $=2126713$, accessed on 2018-04-01).

Unfortunately, judging by myriad reports of consumer borrowing, South African consumers have alarmingly found themselves over-indebted (see e.g. The Reserve Bank of South Africa's Quarterly Bulletin March 2016 , available at https://www.resbank.co.za/Lists/News \% 20and \% 20Publica tions/Attachments/7 195/01 Full \% 20Quarterly \% 20Bulletin \% $20 \%$ E2 \% 80 $\% 93 \%$ 20March \% 202016.pdf, accessed on 2018-04-01). To put this gloomy assertion into perspective one just needs to consider the recent World Bank Survey which concluded that South Africans rank as the biggest borrowers in the world (World Bank 'Africa Region: Sustaining 
Growth and Fighting Poverty amid Rising Global Risks.' Regional Update (2016)). More particularly, according to the National Credit Regulator (NCR)' latest report, 'the total value of new credit granted increased from R120.08 billion to R123.64 billion for the quarter ended September $2017 \ldots$ The number of applications for credit increased by 483,000 from 9.39 million in June 2017 to 9.87 million in September 2017 , representing an increase of $5.15 \%$ for the quarter.' (National Credit Regulator, Consumer Credit Market Report -Third Quarter; September 2017, available at http://www.ncr.org.za/documents/CCMR/CCMR \% 20 2017Q3.pdf, accessed on 2018-04-01).

This is despite the fact that the NCA has since come into effect in 2006, prohibited credit providers from entering into reckless credit agreements (see sections 80 and 81) and this would have been expected to plug the rise in indebtedness. Clearly, the reality is that this has not been the case. For instance, the introduction of the NCA has also seen banks aggressively issue more credit. This is ironic, as the NCA was actually introduced to restrain reckless credit granting.' (Marisit 'Impact of the new National Credit Act on the debt recovery and credit bureau industries' at 27, available at http://www.marisit.co.za/wp-content/ uploads/2014/11/impact-of-the-national-credit-act.pdf, accessed on 2018-04-01). Such an ironic outcome and the regulatory gaps are what the new regulations seek to close (Ntuli in the Department of Trade and Industry Media statement 'The DTI Publishes Affordability Assessment Regulations for Public Comment', available at https://www.thedti.gov.za/ editmedia.jsp?id $=3104$, accessed on 2018-04-01).

The bulk of consumer debt statistics are not only an indictment on the nation's excessive consumption culture (Nyaruwata 'Addressing overindebtedness in South Africa: what role should supply-side and demandside interventions play?', available at www.ekon.sun.ac.za/mini conf2009/nyaruwata_paper.pdf) but are also a manifestation of a milieu which is characterized not only by outdated and lax regulation but also weak enforcement of such legislation. (See for instance Kelly-Low 'The National Credit Act: New parameters for the granting of credit in South Africa' 2007 Obiter 229). This is exacerbated by the prevalence of lenders who market unsolicited loans. This is also compounded by predatory and deceptive advertising (Otto 'Over-indebtedness and applications for debt review in terms of the National Credit Act: Consumers beware! First Rand Bank Ltd v Olivier 2009 SA Merc LJ 272; Kelly-Low 'The prevention and alleviation of consumer over-indebtedness' 2008 SA Merc LJ 200).

This environment is also exacerbated by facilities that offer preapproved credit including credit cards and the laxity on credit providers when it comes to conducting affordability assessments (Otto 'Overindebtedness and applications for debt review in terms of the National Credit Act: Consumers beware! First Rand Bank Ltd v Olivier 2009 SA Merc LJ 272; Kelly-Low 'The National Credit Act: New parameters for the granting of credit in South Africa' 2007 Obiter 229). Furthermore, macroeconomic factors such as higher interest cycles increase the cost of 
credit and add to the erosion of consumers' buying power. With such erosion to their income the consumers are forced to borrow or purchase on credit in order to supplement their income (see generally Hawkins Cost, Volume and Allocation of Consumer Credit in South Africa (FEAsibility, 2003)).

Consumer indebtedness or the propensity to borrow is exacerbated by factors such as the fact that some micro-lenders are not registered as well as the borrowers' financial imprudence or poor financial illiteracy (Piprek 'Financial Literacy Scoping Study and Strategy Project Final Report' (FinMark Trust, 2004); Kelly-Low, Nehf and Rott The Future of Consumer Credit Regulation: Creative Approaches to Emerging Problems (2008) 3). In this setting, borrowers take credit without a proper understanding not only of the costs of servicing the loan, but also of how to manage their finances appropriately. Coupled with lack of transparency on the part of lenders' terms and conditions, this environment has the effect of boosting unsustainable indebtedness. In addition, calamities such as job losses and medical expenditures may have an effect of changing the initial conditions upon which the borrowing contract was based (Willis 'Against financial literacy education' 2008 University of Pennsylvania Law School, Research paper, no.10; DeVaney and Lytton 'Household insolvency: A review of household debt repayment, delinquency, and bankruptcy' 1995 Financial Services Review 137). The South Africa borrowers have not been blameless either. It has been shown that most of them rarely furnish true, adequate or correct information when applying for credit and that impedes credit providers from conducting accurate affordability tests (see statement by Deputy Director-General of Consumer and Corporate Regulation Division at the DTi, Ntuli 'The DTI publishes affordability assessment regulations for public comment', available at https://www.thedti.gov.za/editmedia.jsp?id $=3104$, accessed on 2018-04-01).

The ensuing section seeks to highlight some of the changes that have been brought about by the new dispensation.

\section{Addressing reckless lending through the affordability assessment regime}

As indicated above, the evaluation of the NCA exposed severe gaps in lending practices. More particularly, there was no uniformity in the way affordability assessments were undertaken in the industry. Prior to the coming into effect of the regulations and the National Credit Amendment Act 19 of 2014 (hereafter the 'Amendment Act'), section 82 of the NCA stated that, prior to entering into, or amending, a credit agreement with a consumer 'a credit provider may determine for itself the evaluative mechanisms or models and procedures to be used in meeting its assessment obligations under section 81, provided that any such mechanism, model or procedure results in a fair and objective assessment (my emphasis).' As such, the NCA provided for a flexible credit assessment regime in which the whole process was at the 
discretion of the lender to determine the models for affordability assessments.

Unsurprisingly, however, such a policy resulted in an in inconsistent application of the assessment processes and standards (Paile 'The impact of the National Credit Act on household debt levels in South Africa', available at http://wiredspace.wits.ac.za/bitstream/handle/10539/14754/ The \% 20impact \% 20of \% 20the \% 20National \% 20Credit \% 20Aact \% 20o \% 20household \% 20debt \% 20levels \% 20 in \% 20South \% 20Africa.pdf?seque nce $=1$, accessed on 2018-04-01).

\section{Regulation 23A}

With a view to curbing that, the Amendment Act introduced Regulation 23A into the National Credit Regulations, 2006 with effect from 13 March 2015. More specifically, Regulation 23A's new Affordability Assessment scheme introduces a raft of mandatory policies and practices. These include:

\section{Non-discretionary validation of a consumer's gross income}

In essence much as credit providers are at liberty to make use of their own models determining affordability, such mechanisms must, however, not be inconsistent with the affordability regulations as contained in Regulation 23. Aside from providing that the credit provider conducts a fair and objective assessment, at its enactment, section 81(2) did not contain further guidelines on how the affordability assessment should be conducted nor did any other provision or Regulation contained therein.

Furthermore, such latitude in implementing section 82(2) resulted in a situation which was characterised by discrepancies and gaps in the manner that affordability assessments were conducted. It has been suggested that some credit providers never even undertook such assessments (see e.g. Van Heerden and Renk 'Perspectives on the South African responsible lending regime and the duty to conduct preagreement assessment as a responsible lending practice', available at https://repository.up.ac.za/bitstream/handle/2263/45344/VanHeerden_ Perspectives_2015.pdf; sequence $=1$, accessed on 2018-04-01). On its part, Regulation 23A (3) provides that a 'credit provider must take practicable steps to assess the consumer or joint consumer's discretionary income to determine whether the consumer has the financial means and prospects to pay the proposed credit instalments (my emphasis).' In the case of employed borrowers who receive a salary, it is now mandatory that the lender take practicable steps to validate the borrowers' gross income by demanding through evidence in the form of the latest three payslips; or latest bank statements showing latest three salary deposits. In the case of those who do not receive a salary, the lender must require the latest three documented proof of income; or latest three months bank statements. For self-employed consumers 
including informally employed or those who do not receive a payslip from their employer, the lender must demand to be furnished with the latest three months bank statements or the latest financial statements (see Regulation 23A (3)).

The obligation to calculate discretionary or disposable income and current financial obligations is clearly meant to ensure that there is disclosure through which the lender can determine whether the potential borrower would be in a position to make the payments when they become due without missing payments. In order to enable such a decision to be reached Regulation 23A provides that the lender must consider the gross income (all income earned from whatever source without deductions) of the customer and subtract statutory deductions, necessary expenses as well as other payment commitments disclosed by the consumer. In addition, note should be taken of the consumer's credit record with the credit bureaux.

\section{Calculation of the consumers existing financial income}

Under section 81(2) (iii) the amended section the NCA simply provided that;

A credit provider must not enter into a credit agreement without first taking reasonable steps to assess -

iii) existing financial means, prospects and obligations.

Under the new dispensation, not only must the lender assess the consumer's income, he or she must actually calculate the consumers existing financial means, prospects and obligations. To assist in that regard, not only does Regulation 23A provides for a template, a minimum expense norms table but also a requirement for '(a) credit providers to ascertain gross income; (b) statutory deductions and minimum living expenses to be deducted to arrive at a net income, which must be allocated for payment of debt instalments; and (c) when existing debt obligations are taken into account, the credit provider must calculate discretionary income to enable the consumer to satisfy any new debt.' In essence, therefore, Regulation 23A buttresses section 81(2) (a) (iii) by providing a standardised method which assists in deciding credit affordability. To ensure that the lender has discretion, Regulation 23A (11) allows the lender, on exceptional basis and where the same is warranted, to accept the consumer's declared minimum expenses which are lower than those set out Minimum Expense Norms table. This is permissible for as long as the questions prescribed by or set out in Regulation 23A are satisfactorily answered by the consumer. Such a practicable framework goes a long way towards assisting the lender in determining whether the consumer would be able to afford the credit. In like manner, that evaluative mechanism avoids a situation where the borrower attempts to under-declare their expenses with a view to create an impression that they are credit-worthy. 


\section{Debt re-payment history as a consumer under credit agreements}

In general, section 82(2) of the NCA provides that the lender should not enter into a credit agreement without first taking reasonable steps to assess the debt re-payment history of a consumer. This requirement has now been strengthened by a duty to undertake that assessment within seven business days immediately preceding the initial approval of credit or the increasing of an existing credit limit. In terms of mortgages that must be done within fourteen business days. This has an obvious advantage in that it enables that assessment to be undertaken based on current information (see e.g. Ramsay Consumer Law and Policy: Text and Materials on Regulating Consumer Markets, Bloomsbury Publishing, 2012).

\section{Avoiding double counting}

In order to avoid exposure to, and the unfairness that would come from double counting, section $23 \mathrm{~A}(14)$ provides that '[w] here a credit agreement is entered into on a substitutionary basis in order to settle off one or more existing credit agreement, a credit provider must:

(a) record that the credit being applied for is to replace other existing credit agreement/s; and

(b) take practicable steps to ensure that such credit is properly used for such purposes.

\section{Disclosure of the credit cost multiple and the total cost of credit}

It is common-cause that financial service providers often have better information relating to, for instance, the fees and risks of their products or services than consumers (Agarwal, Chomsisengphet, Mahoney and Stroebel 'Regulating consumer financial products: Evidence from credit cards' 2014 The Quarterly Journal of Economics 111; Bertrand and Morse 'Information disclosure, cognitive biases, and payday borrowing' 2011 The Journal of Finance 1865). Owing to asymmetric information, transparency can only be brought about by requiring lenders to provide consumers with information that would enable them to make informed decisions. Not only does that requirement enhance transparency but it also goes a long way towards curbing illegal or abusive collection practices. To that end regulatory intervention in South Africa has come in the form of section 23(15) which compels the credit provider to disclose the total cost of finance to the customer. In particular, the section provides that:

A credit provider must:

(a) disclose to the consumer the credit cost multiple and total cost of credit in the pre-agreement statement and quotation; 
(b) ensure that the credit cost multiple disclosures for credit facilities is based on one year of full utilisation up to the credit limit proposed;

(c) ensure that the attention of the prospective consumer is drawn to the credit cost multiple and that the cost of credit as disclosed, is understood by the prospective consumer;

(d) disclose a total cost of credit which includes but not limited to, the following items:-

(i) the principal debt;

(ii) interest;

(iii) initiation fee...

A responsible disclosure obligation in this manner is crucial for meeting the requirement to treat consumers fairly as inter alia, it enables customers to compare the costs connected borrowing across both the products and lenders. Likewise, it enhances competition among lenders or sellers of financial products (Renuart, Keest and Carter The Cost of Credit: Regulation, Preemption, and Industry Abuses (National Consumer Law Center, 2009); Faircloth and Mack Problems Surrounding the Mortgage Origination Process: Congressional Hearing (DIANE Publishing, 2000)).

\section{Brief remarks on the new lending requirements}

Credit has been characterized as the lifeblood of the economy. (See e.g. Tiller 'The subprime crisis and the effects on the U.S. banking industry', available at https://www.lagrange.edu/resources/pdf/citations/2009/ 07Business_Tiller.pdf, accessed on 2018-04-01). As such it cannot be doubted that access to credit is sometimes a crucial component in attaining financial inclusion (Mehrotra and Yetman 'Financial inclusion issues for central banks' 2015 BIS Quarterly Review 84; Bilbiie 'Limited asset market participation, monetary policy and (inverted) aggregate demand logic' 2008 Journal of Economic Theory 162). The NCA arguably recognises that (see e.g. The Microfinance Review 2013 'From Microfinance to Financial Inclusion' at https://www.bankseta.org.za/ downloads/BANKSETA \% 20Microfinance \% $20 \%$ 20Review \% 20Report \% 202013.pdf, accessed on 2018-04-01). Hence the dual role it plays (or the regulatory dilemma it is exposed to); on one hand it recognises the need to promote the development of the credit market and at the same time, it is expected to protect the consumer by ensuring transparent, fair and responsible lending (in this regard, see the objectives in section 3 of the NCA. See also Porteuos 'Policy focus note 2: Consumer protection in credit markets', available at http://www.microfinancegateway.org/sites/ default/files/mfg-en-paper-consumer-protection-in-credit-markets-jul-20 09.pdf, accessed on 2018-04-01).

Much as that is a truism, and especially owing to the alarming statistics alluded to above, it is essential that regulators do not lose sight of the devastating effects of irresponsible lending as well as the use of credit products. In an ideal world, and according to the neo-classical 
model of market regulation the customer is regarded as 'a rational actor able to make responsible decisions best suited to his or her needs, assisted by the provisions of relevant, accurate and timely comparative information' (Devenney Consumer Credit, Debt and Investment in Europe (2014) at 167. See also Prigden 'Putting some teeth in TILA: From disclosure to substantive regulation in the Mortgage Reform and AntiPredatory Money Lending Act of 2010' 2012 Loyola Consumer Law Review 615).

In reality, however, there is a need for paternalistic intervention. Such an approach is premised on that perception that oftentimes consumers tend to make adverse choices and so a paternalistic policy seeks to minimise this risk by reshaping consumer's situation by, for instance, encouraging or pressurising the consumer into a choice that enhances his benefits by either swelling the cost of the detrimental activity, or by limiting the consumer's liberty enter into that activity (see generally Epstein 'The Neoclassical economics of consumer contracts' 2008 Minn $L$ Rev 803; Kant Political Writings (1991) 74). In essence, such an approach seeks to protect the consumer not only from information asymmetries but also against being irrational or against self-gratification which culminates in exposure to indebtedness. As such, there is a need to strike a delicate balance between the need to support the financial sector's lending objective and the implementation of measures aimed protecting the consumer (Camerer et al 'Regulation for conservatives: Behavioural economics and the case for asymmetric paternalism' (2002) $U \mathrm{~Pa} \mathrm{~L}$ Rev 1211; Irwin Implications of behavioural economics for regulatory reform in New Zealand (2010)). This is what the Affordability Assessment regulations attempt to achieve by making mandatory provisions which were not enshrined in the NCA.

Much as it is lauded as a positive step towards minimizing indebtedness, the new dispensation seems to have failed to address the underlying factors that engender demand for credit (Gropp 'Did consumers want less debt? Consumer credit demand versus supply in the wake of the 2008-2009 financial crisis' (2014) Federal Reserve Bank of San Francisco Working Paper 2014-08). For as long as the current macroeconomic environment which pushes consumers to supplement their finances persists, consumers will continue to borrow.

On account of the fact that the new regulations bring uniformity in the provision of credit, they undoubtedly are a game changer. However, the mere crafting of a high-sounding piece of legislation should not be the end in itself. Rather, policy-makers must be proactive and not reactionary (for this recommendation see for instance Wilson International Responses to Issues of Credit and Over-Indebtedness in the Wake of Crisis (Ashgate, 2013); van Heerden and Renke 'Perspectives on the South African responsible lending regime and the duty to conduct pre-agreement assessment as a responsible lending practice', available at http://repository.up.ac.za/dspace/bitstream/handle/2263/45344/VanHee rden_Perspectives_2015.pdf?sequence $=1$ \&isAllowed $=y$, accessed on 
2018-04-01). They should be able to respond to issues happening 'on the ground' in as far as the credit market is concerned. In like manner, there is need to promote financial inclusion as well as heightened consumer financial education such as budgeting as well as simple financial concepts such as interest. It would also be beneficial if consumers understood the potentially devastating effects of ill-managed debt (Hilgert and Hogarth 'Household financial management: The connection between knowledge and behaviour' 2003 Federal Reserve Bulletin 301; Sebstad and Cohen 'Assessing the outcomes of financial education' Working Paper No.3. Microfinance Opportunities, Washington DC, 2006).

\section{Conclusions}

The embarrassing statistics that have projected South Africa among the worst in the world justify the recent paternalistic regulatory intervention. However, the new framework ushered by the Affordability Assessment regulations is just the beginning and the government should not be overly optimistic about the fundamental paradigm shift. What needs to be borne in mind by all stakeholders is that on its own this structure will not solve the scale or the age-old problem of reckless lending. There is a need for concerted effort and new strategies by all stakeholders to address the social and economic factors that fuel the problem. These could include exploring the possibility of microfinance platforms that offer low-interest loan schemes (The International Financial Consumer Protection Organisation 'FinCoNet report on responsible lending: Review of supervisory tools for suitable consumer lending practices', available at http://www.finconet.org/FinCoNet-Responsible-Lending-2014.pdf, accessed on 2018-04-01). These could avert problems debt arising for example, from opportunistic lending practices.

Perhaps, as the government celebrates the new regime under Regulation 23A, a cautionary sum up would be appropriate: 'regulation without necessary enforcement capacity can hinder and damage nascent credit markets in developing countries by causing further fragmentation. Greater emphasis on consumer protection is necessary; but deciding on when, and what form, to introduce it is a vital dimension of the regulator's dilemma today (Porteuos 'Policy focus note 2: Consumer protection in credit markets' at 16, available at http://www. microfinancegateway.org/sites/default/files/mfg-en-paper-consumerprotection-in-credit-markets-jul-2009.pdf, accessed on 2018-04-01).

H KAWAZDA

University of the Witwatersrand 